\title{
Dimensional Stability of Plywood Panels Made from Thermally Modified Poplar Veneers in the Conditions of Variable Air Humidity
}

\section{Stabilnost dimenzija ploča od uslojenog drva izrađenih od toplinski modificiranih topolovih furnira u uvjetima promjenjive vlažnosti zraka}

\author{
Original scientific paper - Izvorni znanstveni rad \\ Received-prispjelo: 17. 5. 2012. \\ Accepted-prihvaćeno: 21. 6. 2013. \\ UDK: $630 * 812.227 ; 630 * 832.282 .1 ; 674.031 .623 .25$ \\ doi:10.5552/drind.2013.1223
}

\begin{abstract}
Some properties of plywood panels made from untreated and thermally modified $\left(90\right.$ min. at $\left.200^{\circ} \mathrm{C}\right)$ poplar veneers and their combinations have been analyzed. The change in equilibrium moisture content and the change in dimensions of the samples conditioned above water in closed containers were examined. The analysis using F-test (ANOVA) at the significance level of 95\% confirmed that, regarding moisture content, all combinations of plywood panels differed significantly from the control panels. However, the analysis of thickness swelling showed that there was no significant difference among the plywood panels of similar construction. The highest values of anti-swelling efficiency were shown by plywood panels made from thermally modified veneers.
\end{abstract}

Key words: thermal modification, poplar veneer, plywood panels, dimensional stability, ASE

SAŽETAK • U radu su istražena neka svojstva ploča izrađenih od nemodificiranih $i$ od termički modificiranih $\left(90\right.$ min pri $\left.200{ }^{\circ} \mathrm{C}\right)$ topolovih furnira te njihovih kombinacija. Istraživana je promjena ravnotežnog sadržaja vode i promjene dimenzija uzoraka u uvjetima iznad vode u zatvorenim posudama. Analiza uz pomoć F-testa (ANOVA) na razini značajnosti od $95 \%$ potvrdila je da se, s obzirom na sadržaj vode, sve ispitne ploče znatno razlikuju od kontrolnih ploča. Međutim, analiza podataka o debljinskom bubrenju pokazala je da ne postoji značajna razlika između ploča slične konstrukcije. Najveću učinkovitost u sprječavanju debljinskog bubrenja pokazale su ploče izrađene od toplinski modificiranih furnira.

Ključne riječi: toplinska modifikacija, topolov furnir, ploče od uslojenog drva, dimenzijska stabilnost, ASE

\section{INTRODUCTION}

1. UVOD

The purpose of thermal wood modification is to obtain the products of improved dimensional stability, decay resistance and durability. During thermal modification, the most thermally labile of wood polymeric components begin to degrade inside the cell wall (primarily hemicelluloses and in later stages also cellulose) resulting in the production of furan compounds, such as furfural and hydroxymethilfurfural

\footnotetext{
${ }^{1}$ The authors are associate professor, assistant and junior assistant at the Faculty of Forestry, Department of Wood Processing, University of Belgrade, Belgrade, Serbia.

${ }^{1}$ Autori su izvanredni profesor, asistent i mlađa asistentica Odjela za preradu drva, Šumarski fakultet, Sveučilište u Beogradu, Beograd, Srbija
} 
(Rowell et al., 2009). At high temperatures, the links inside the lignin complex are degraded. This phase of increased lignin reactivity is characterized by the production of various condensation reactions between aldehyde and lignin, as well as by self condensation of lignin (Tjeerdsma et al., 2005).

The incurred chemical changes have a positive effect on the decrease in hydrofility of the treated material. According to Boonstra and Tjeerdsma (2006), the decrease in wood hygroscopicity during thermal treatments is the result of:

- depolymerization of carbohydrates (especially hemicelluloses), which results in the decrease in the number of free hydroxyl groups;

- increasing the share of crystal zone in the cellulose where hydroxyl groups are not readily available;

- further cross linking of the lignin, by which the availability of hydroxyl groups is additionally decreased.

The positive influence of thermal wood modification on the decrease in hydrofility, swelling and shrinkage of treated wood was confirmed by numerous researches (Kocaefe et al., 2008; Yongjian et al., 2010; Poncsak et al., 2010; Sinković et al., 2011; Zdravković and Lovrić, 2010). As opposed to these positive effects, thermal wood modification causes the decrease in most mechanical properties of wood. The two crucial factors affecting the final quality of treated wood are temperature and time (Kubojima et al., 2000; Poncsak et al., 2006; Shi et al., 2007; etc.).

Poplar (Populus nigra) is a species that, despite its relatively low density $\left(\rho_{0}=0.41 \mathrm{~g} / \mathrm{cm}^{3}\right)$, significantly changes its dimensions in the conditions of variable air humidity $\left(\alpha_{\mathrm{v}}=14.3 \%\right)$ (Šoškić and Popović, 2002). Also, poplar tends to form reaction wood (tension wood), which additionally complicates the drying process and influences the deformation of saw boards (Glavaški and Popadić, 1997). For this reason, poplar is most commonly used in the production of pulp and paper and in veneer and plywood production.

In the plywood panel production process, the crosslinking of adjacent veneer layers decreases plywood shrinkage, splitting and warping. In addition, thermal treatments cause the decrease in the treated material affinity for water. One of the measures for wood affinity for water is the contact angle. The measurements of contact angle in earlier papers showed that on the thermally treated veneers, (Zdravković and Lovrić, 2010), OSB panels (Unsal et al., 2010) and plywood panels (Candan et al., 2012), contact angle increases with increasing of temperature and treatment duration, which indicates decreasing treated material affinity for water. Improvement of physical properties of LVL made of thermally treated poplar veneers were proved by Nazerian and Ghalehno (2011).

In this paper the possibility of production of plywood panels composed of thermally treated veneers was investigated in an attempt to obtain the material of improved dimensional stability.

\section{MATERIAL AND METHODS}

\section{MATERIJAL I METODE}

The materials used in this study are poplar veneers with a nominal thickness of $3 \mathrm{~mm}$. The veneers were selected by random sample method from the storage of plywood mill "Novi Drvni Kombinat" from Sremska Mitrovica. The materials were shipped to laboratory facility of the company "Tarket" at Bačka Palanka. Based on the previous laboratory research (Lovrić and Zdravković, 2009), it was found that thermal treatment at $200{ }^{\circ} \mathrm{C}$ for 90 min gave the optimal ratio between the loss of volume shrinkage and the loss of mass of poplar veneer (loss of shrinkage was $7.62 \%$ and loss of mass was $6.49 \%$ ). Most of the material was thermally treated by the above regime and some of the material was left untreated for the production of control samples.

Thermal modification was conducted in the presence of steam as protection agent, so the treatment can be assumed as steam-heat treatment. In the treatment regime, the conditioning phase was also included in addition to heating phase, thermal treatment phase and cooling phase. The conditioning phase of 2-hour duration started at the moment when the temperature dropped below $100{ }^{\circ} \mathrm{C}$.

After thermal modification, veneer sheets were cut into $80 \mathrm{~cm}$ by $80 \mathrm{~cm}$ and prepared for pressing. Melamine urea formaldehyde adhesive was applied by hand roller-spreader by spreading rate of $200 \mathrm{~g} / \mathrm{m}^{2}$, veneers were arranged into the corresponding lay-ups and pressed according to the following regime: pressing temperature $t=85{ }^{\circ} \mathrm{C}$, total pressure $P_{\mathrm{t}}=15 \mathrm{MPa}$, pressing time $Z_{1}=10 \mathrm{~min}$ for three-layer plywood and $Z_{2}=13$ min for five-layer plywood.

The following combinations of plywood were made: three-layer plywood composed of untreated veneers - $3 \mathrm{~N}$ (control group), three-layer plywood composed of outer layers of thermally treated veneers and inner layer of untreated veneer - TNT, three-layer plywood composed of treated veneers - 3T, five-layer plywood of alternately composed treated and untreated veneers -TNTNT, five-layer plywood with outer layers of treated veneers and core layer of untreated veneers - T3NT, and five-layer plywood composed solely of treated veneers $-5 \mathrm{~T}$.

Twenty samples of $5 \mathrm{~cm}$ by $5 \mathrm{~cm}$ were cut from each panel. The mass and dimensions of all samples were measured and dried to oven-dry condition, and measured again. Based on the measurements, the board moisture content (MC) (EN 322) and density (EN 323) were calculated. After measurements, the samples were arranged in closed containers above water and the changes in their $M C$ and dimensions were monitored. The measurements of mass (for $M C$ calculations) and thickness were performed every day during the first week, and after that every seven days.

After seven weeks (when the sample mass and thickness became stable), the samples were left to float on the water surface. The sample mass and thickness were measured again in the following week, and then 
they were immersed in water for another week. After this period, final measurements of mass and thickness were performed and the obtained data was used for calculations of swelling and $M C$ for each plywood construction and for the construction of the corresponding curves representing the changes during the study period.

\section{RESULTS AND DISCUSSION}

\section{REZULTATI I RASPRAVA}

\subsection{Initial plywood density, moisture content and thickness}

3.1. Početna gustoća ploča, sadržaj vode i debljina

It is obvious that, with the increase in the content of thermally treated veneers in the lay-up, plywood density increases and $M C$ decreases. The decrease in $M C$ is expected because during the thermal treatment, the number of free hydroxyl groups decreases and the possibility of moisture absorption from outdoor environment is reduced.

The increase in plywood density is probably caused by the following factors:

- greater amount of plywood thickness loss during pressing due to diminished mechanical properties of thermally modified wood, caused by collapse of thermally modified cell walls, (Awoyemi and Jones, 2010);

- higher plywood plasticity (in the process of thermal modification, hemicelluloses and celluloses are first decomposed, and the effect on lignin is much lower), which causes a lower "spring back" effect (Table 2).

Average thickness of the samples cut from the corresponding plywood panels are shown in Table 2. It can be seen that, under the same pressing regime, plywood thickness decreases if the content of thermally treated veneers in the lay-up increases. The exception is plywood TNTNT, which is somewhat thicker than plywood T3NT.

\subsection{Changes in plywood dimensions and $M C$ \\ 3.2. Promjene dimenzija ploča i sadržaja vode}

To determine how the study plywood panels react to the conditions of higher air humidity, the plywood samples were arranged in closed containers above water. During the first week, $M C$ and thickness of the samples increased rapidly, especially during the first three days (Figure 1). The control sample - 3N showed significantly greater changes in $M C$ and thickness compared to other plywood construction. Similar results were shown in the research by Nazerian et al. (2011), who determined the highest values of radial, tangential and longitudinal swelling in LVL samples with untreated veneers.

After the seventh day, $M C$ of the control sample was $M C=19.32 \%$, and thickness change accounted for $\beta_{\mathrm{s}}=4.08 \%$. The lowest variations of $M C$ and thickness were measured in three-layer and five-layer plywoods composed of thermally modified veneers only $\left(3 \mathrm{~T}-M C=13.15 \%, \beta_{\mathrm{S}}=2.71 \%\right.$; $5 \mathrm{~T}-M C=12.02$ $\left.\%, \beta_{\mathrm{s}}=2.25 \%\right)$.

Table 1 Density of plywood panels and MC at the moment of sample cutting

Tablica 1. Gustoća ploča i sadržaj vode u trenutku izrade uzoraka

\begin{tabular}{|c|c|c|c|c|c|c|}
\hline \multirow{2}{*}{$\begin{array}{c}\text { Panel type } \\
\text { Vrsta ploče }\end{array}$} & \multicolumn{3}{|c|}{$\begin{array}{c}\text { Three-layer plywood panels } \\
\text { Troslojne ploče }\end{array}$} & \multicolumn{3}{c|}{$\begin{array}{c}\text { Five-layer plywood panels } \\
\text { Peteroslojne ploče }\end{array}$} \\
\cline { 2 - 7 } & $3 \mathrm{~N}$ & $\mathrm{TNT}$ & $3 \mathrm{~T}$ & $\mathrm{~T} 3 \mathrm{NT}$ & $\mathrm{TNTNT}$ & $5 \mathrm{~T}$ \\
\hline $\begin{array}{c}\text { Density, g/cm } \\
\text { Gustoća, g/cm }\end{array}$ & 0.394 & 0.425 & 0.466 & 0.385 & 0.426 & 0.506 \\
\hline $\begin{array}{c}\text { MC, \% } \\
\text { Sadržaj vode, \% }\end{array}$ & 6.43 & 5.70 & 5.27 & 6.31 & 6.17 & 5.50 \\
\hline
\end{tabular}

3N (control group) - three-layer plywood composed of untreated veneers / troslojne ploče od nemodificiranih furnira; TNT - three-layer plywood composed of outer layers of thermally treated veneers and inner layer of untreated veneer / troslojne ploče s vanjskim toplinski modificiranim furnirima i unutarnjim nemodificiranim furnirom; 3T - three-layer plywood composed of treated veneers / troslojne ploče od toplinski modificiranih furnira; TNTNT - five-layer plywood of alternately composed treated and untreated veneers / peteroslojne ploče izrađene od kombinacije modificiranih i nemodificiranih furnira; $\mathrm{T} 3 \mathrm{NT}$ - five-layer plywood with outer layers of treated veneers and core layer of untreated veneers / peteroslojne ploče izrađene s vanjskim modificiranim furnirima i unutarnjim nemodificiranim furnirima; 5T - five-layer plywood composed solely of treated veneers / peteroslojne ploče izrađene samo od modificiranih furnira

Table 2 Average thickness of samples of different plywood panels

Tablica 2. Prosječna debljina uzoraka različitih ploča od uslojenog drva

\begin{tabular}{|c|c|c|c|c|c|c|}
\hline \multirow{2}{*}{$\begin{array}{c}\text { Panel type } \\
\text { Vrsta ploče }\end{array}$} & \multicolumn{3}{|c|}{$\begin{array}{c}\text { Three-layer plywood panels } \\
\text { Troslojne ploče }\end{array}$} & \multicolumn{3}{c|}{$\begin{array}{c}\text { Five-layer plywood panels } \\
\text { Peteroslojne ploče }\end{array}$} \\
\cline { 2 - 7 } & $3 \mathrm{~N}$ & TNT & $3 \mathrm{~T}$ & T3NT & TNTNT & $5 \mathrm{~T}$ \\
\hline $\begin{array}{c}\text { Thickness, } \mathrm{mm} \\
\text { Debljina, } \mathrm{mm}\end{array}$ & 8.71 & 8.52 & 8.48 & 13.77 & 14.08 & 13.28 \\
\hline
\end{tabular}



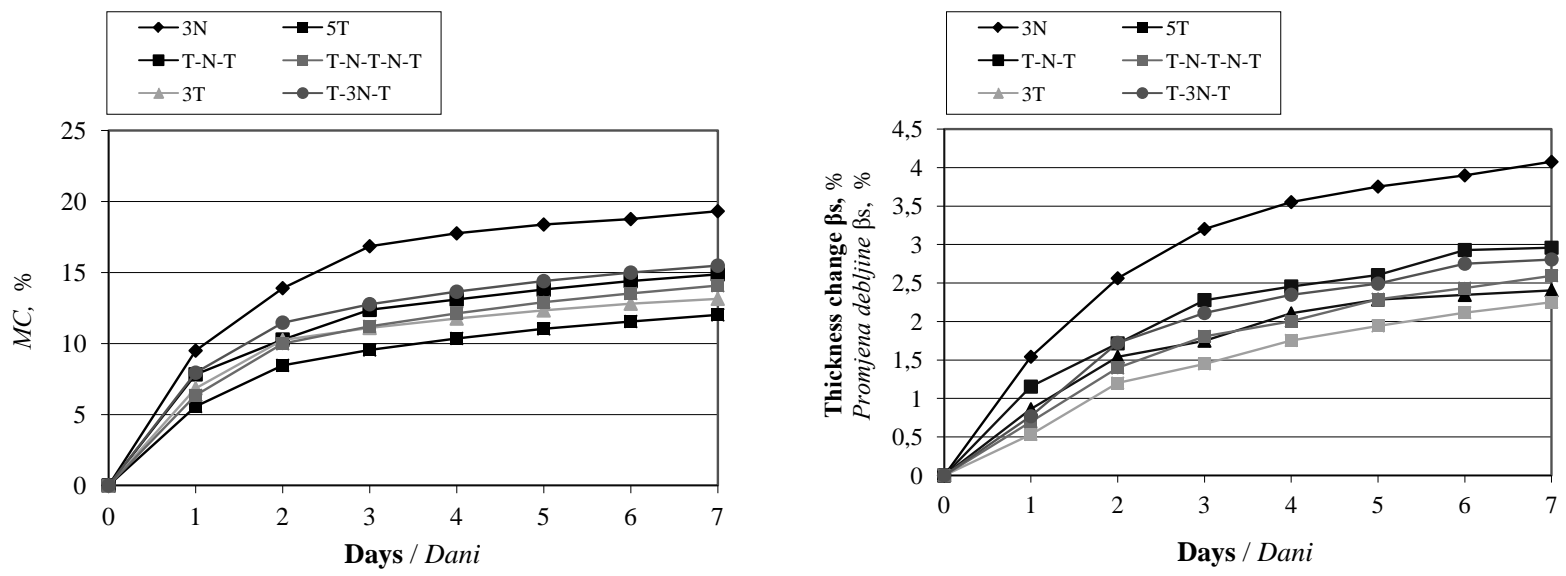

Figure 1 Changes in MC and thickness of boards during the first week

Slika 1. Promjene sadržaja vode i debljine ploča tijekom prvog tjedna
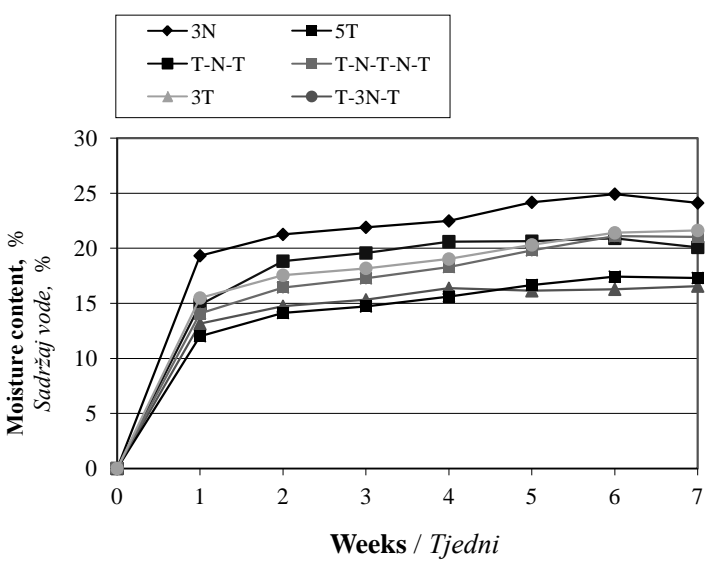
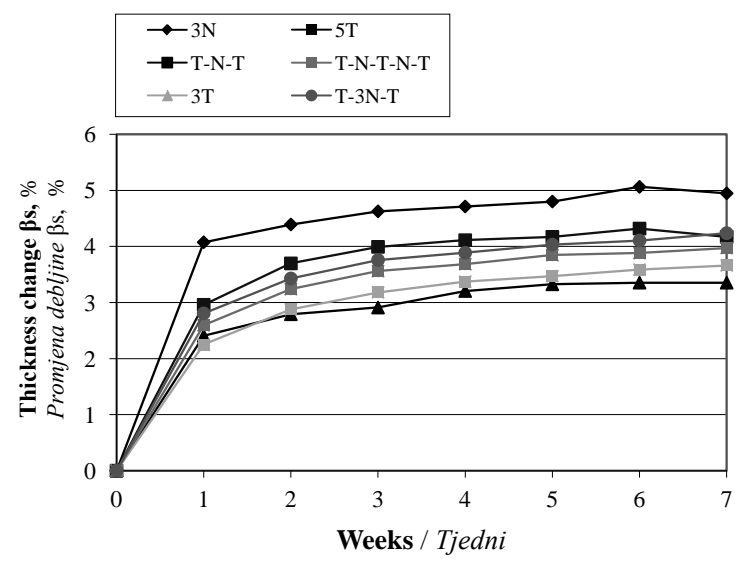

Figure 2 Changes in MC and thickness of boards during the whole experiment Slika 2. Promjene sadržaja vode i debljine ploča tijekom cijelog eksperimenta

With the progression of the experiment, all the observed values were slightly increased until the end of the sixth week from the beginning, and they became stable in the seventh week (Figure 2). Plywood MC and total thickness swelling reached the maximum after floating and immersing of the samples for eight and nine weeks (Table 3 ).

The analysis of graphs in Figure 1 shows that the separation of the presented curves into three groups starts after the first week. The lowest values of thickness swelling were attained by the samples cut from plywood made exclusively of treated veneers (boards 3T and 5T), the middle group of curves consisted of plywood made of a combination of treated and untreat- ed veneers (boards TNT, T3NT and TNTNT), while the highest values were shown by the control board (board 3N). This trend continued to the end of the seventh week when the measured values became stable (Figure 2).

Similar effect of thermal treatments on EMC of different wood species was stated by Kamdem et al. (2002), Akyildiz and Ates (2008), and on change of thickness swelling (TS) by Cao et al. (2010), Tjeerdsma et al. (1998) and Yildiz (2002).

Maximum changes in dimensions were achieved only after the samples were immersed in water (Table 3) without an essential effect on the observed trend. Figure 3 shows the effect of plywood composition on dimension

Table 3 The maximum MC and total thickness swelling of the samples

Tablica 3. Najveći sadržaj vode i ukupno debljinsko bubrenje uzoraka

\begin{tabular}{|c|c|c|c|c|c|c|c|}
\hline \multirow{2}{*}{\begin{tabular}{c}
\multirow{2}{*}{$\begin{array}{c}\text { Panel type } \\
\text { Vrsta ploče }\end{array}$} \\
\cline { 2 - 8 }
\end{tabular}} & \multicolumn{3}{c|}{$\begin{array}{c}\text { Three-layer plywood panels } \\
\text { Troslojne ploče }\end{array}$} & \multicolumn{3}{c|}{$\begin{array}{c}\text { Five-layer plywood panels } \\
\text { Peteroslojne ploče }\end{array}$} \\
\hline \multirow{3}{*}{ MC \% $\%$} & $\begin{array}{c}\text { Floating } \\
\text { plutanje }\end{array}$ & 122.91 & 118.43 & 110.36 & 129.05 & 109.63 & 91.11 \\
\cline { 2 - 8 } & $\begin{array}{c}\text { Immersing } \\
\text { uranjanje }\end{array}$ & 143.25 & 131.98 & 120.01 & 149.59 & 124.52 & 101.74 \\
\hline \multirow{3}{*}{$\beta_{\mathrm{s}}, \%$} & $\begin{array}{c}\text { Floating } \\
\text { plutanje }\end{array}$ & 5.56 & 4.64 & 3.56 & 4.55 & 4.26 & 3.87 \\
\cline { 2 - 8 } & $\begin{array}{c}\text { Immersing } \\
\text { uranjanje }\end{array}$ & 5.62 & 4.70 & 3.71 & 4.69 & 4.47 & 4.00 \\
\hline
\end{tabular}




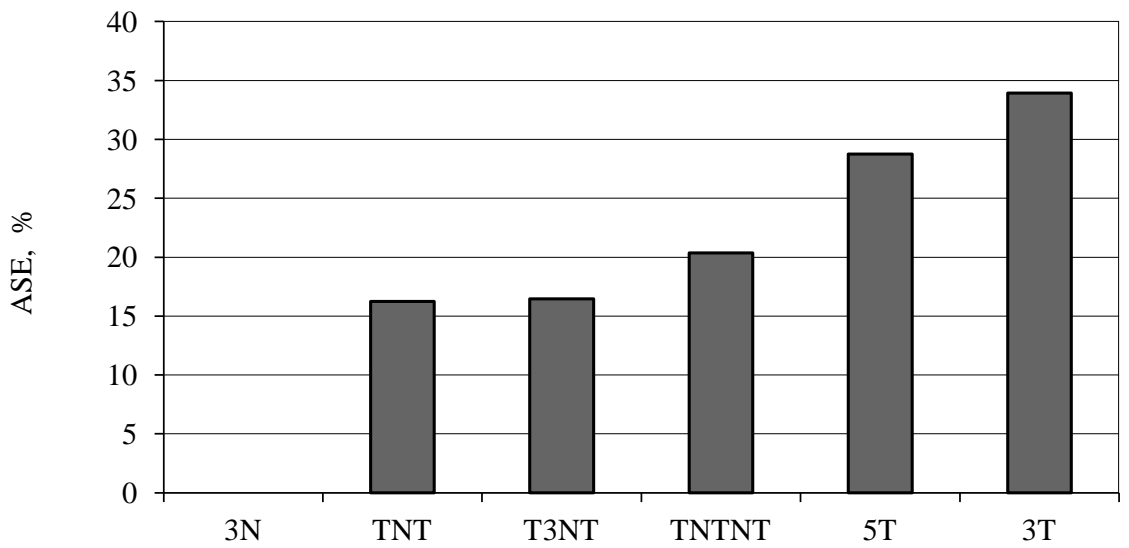

Figure 3 Achieved values of ASE after the sample immersion Slika 3. Postignute vrijednosti ASE nakon uranjanja uzoraka

stability. The bars present the values of anti-swelling efficiency (ASE) calculated in relation to the achieved value of the control board $(3 \mathrm{~N})$ thickness swelling.

The values of maximum $M C$ (calculated after immersion - Table 3) were not so strictly grouped. The smallest value of $M C$ was observed for five-layer plywood exclusively composed of thermally treated veneers $(5 \mathrm{~T}-M C=101.74 \%)$. The three-layer plywood composed of only thermally treated veneers (3T) showed the maximum $M C$ values, similar to plywood
TNTNT, while plywood T3NT was the closest to the control plywood $3 \mathrm{~N}$.

Statistical analysis of the obtained values was performed to determine whether the calculated values of average changes in $M C$ and thickness swelling were due to coincidence, or due to different behavior of the study boards. The values calculated after seven weeks from the beginning of the experiment were taken as the reference point. The main statistical indicators of $M C$ and thickness swelling are shown in Table 4 and 5.

Table 4 The main statistics - MC after seven weeks

Tablica 4. Rezultati statističke analize podataka o sadržaju vode nakon sedam tjedana

\begin{tabular}{|c|c|c|c|c|c|c|}
\hline \multirow{2}{*}{$\begin{array}{c}\text { Panel type } \\
\text { Vrsta ploče }\end{array}$} & \multicolumn{3}{|c|}{$\begin{array}{c}\text { Three-layer plywood panels } \\
\text { Troslojne ploče }\end{array}$} & \multicolumn{3}{c|}{$\begin{array}{c}\text { Five-layer plywood panels } \\
\text { Peteroslojne ploče }\end{array}$} \\
\cline { 2 - 7 } & $3 \mathrm{~N}$ & $\mathrm{TNT}$ & $3 \mathrm{~T}$ & $\mathrm{~T}$ NT & TNTNT & $5 \mathrm{~T}$ \\
\hline $\begin{array}{c}\text { Number of samples } \\
\text { Broj uzoraka }\end{array}$ & 20 & 20 & 20 & 20 & 20 & 20 \\
\hline $\begin{array}{c}\text { Average value } \\
\text { Srednja vrijednost }\end{array}$ & 24.12 & 20.08 & 16.56 & 21.62 & 21.03 & 17.30 \\
\hline $\begin{array}{c}\text { Standard deviation } \\
\text { Standardna devijacija }\end{array}$ & 0.62 & 0.70 & 0.53 & 0.67 & 0.80 & 0.58 \\
\hline $\begin{array}{c}\text { Coeff. of variation } \\
\text { Koeficijent varijacije }\end{array}$ & 2.59 & 3.46 & 3.17 & 3.08 & 3.82 & 3.37 \\
\hline $\begin{array}{c}\text { Standard error } \\
\text { Standardna pogreška }\end{array}$ & 0.14 & 0.16 & 0.12 & 0.15 & 0.18 & 0.13 \\
\hline
\end{tabular}

Table 5 The main statistics - thickness swelling after seven weeks

Tablica 5. Rezultati statističke analize podataka o debljinskom bubrenju nakon sedam tjedana

\begin{tabular}{|c|c|c|c|c|c|c|}
\hline \multirow{2}{*}{$\begin{array}{c}\text { Panel type } \\
\text { Vrsta ploče }\end{array}$} & \multicolumn{3}{|c|}{$\begin{array}{c}\text { Three-layer plywood panels } \\
\text { Troslojne ploče }\end{array}$} & \multicolumn{3}{c|}{$\begin{array}{c}\text { Five-layer plywood panels } \\
\text { Peteroslojne ploče }\end{array}$} \\
\cline { 2 - 7 } & $3 \mathrm{~N}$ & $\mathrm{TNT}$ & $3 \mathrm{~T}$ & $\mathrm{~T} 3 \mathrm{NT}$ & TNTNT & $5 \mathrm{~T}$ \\
\hline $\begin{array}{c}\text { Number of samples } \\
\text { Broj uzoraka }\end{array}$ & 20 & 20 & 20 & 20 & 20 & 20 \\
\hline $\begin{array}{c}\text { Average value } \\
\text { Srednja vrijednost }\end{array}$ & 4.95 & 4.17 & 3.35 & 4.24 & 3.97 & 3.66 \\
\hline $\begin{array}{c}\text { Standard deviation } \\
\text { Standardna devijacija }\end{array}$ & 0.82 & 0.36 & 0.55 & 0.52 & 0.30 & 0.63 \\
\hline $\begin{array}{c}\text { Coeff. of variation } \\
\text { Koeficijent varijacije }\end{array}$ & 16.61 & 8.58 & 16.52 & 12.20 & 7.48 & 17.23 \\
\hline $\begin{array}{c}\text { Standard error } \\
\text { Standardna pogreška }\end{array}$ & 0.18 & 0.08 & 0.12 & 0.12 & 0.07 & 0.14 \\
\hline
\end{tabular}


Table 6 Calculated $p$-values according to the attained $M C$

Tablica 6. $p$-vrijednosti pri usporedbi podataka o sadržaju vode

\begin{tabular}{|c|c|c|c|c|c|c|}
\hline $\begin{array}{c}\text { Panel type } \\
\text { Vrsta ploče }\end{array}$ & 3N & TNT & 3T & $\mathbf{5 T}$ & TNTNT & T3NT \\
\hline 3N & - & 0.0000 yes & 0.0000 yes & 0.0000 yes & 0.0000 yes & 0.0000 yes \\
\hline TNT & - & - & 0.0000 yes & 0.0000 yes & 0.0003 yes & 0.0000 yes \\
\hline 3T & - & - & - & 0.0002 yes & 0.0000 yes & 0.0000 yes \\
\hline 5T & - & - & - & - & 0.0000 yes & 0.0000 yes \\
\hline TNTNT & - & - & - & - & - & 0.0159 yes \\
\hline
\end{tabular}

Table 7 Calculated $p$-values according to the attained thickness swelling

Tablica 7. $p$-vrijednosti pri usporedbi podataka o debljinskom bubrenju

\begin{tabular}{|c|c|c|c|c|c|c|}
\hline $\begin{array}{c}\text { Panel type } \\
\text { Vrsta ploče }\end{array}$ & 3N & TNT & 3T & $\mathbf{5 T}$ & TNTNT & T3NT \\
\hline 3N & - & 0.0004 yes & 0.0000 yes & 0.0000 yes & 0.0000 yes & 0.0023 yes \\
\hline TNT & - & - & 0.0000 yes & 0.0032 yes & 0.0649 no & 0.6417 no \\
\hline 3T & - & - & - & 0.1086 no & 0.0001 yes & 0.0000 yes \\
\hline 5T & - & - & - & - & 0.0524 no & 0.0031 yes \\
\hline TNTNT & - & - & - & - & - & 0.0552 no \\
\hline
\end{tabular}

The statistical ANOVA was performed using $F$-test (Statgraphics software) at the significance level of $95 \%$. Table 6 and 7 show the calculated $p$-values for F-test. All the values below 0.05 are bolded in the Tables and they show that there are significant differences among the observed samples.

Based on the analysis of data on $M C$ reached after seven weeks (Table 6), it can be concluded that there is a significant difference among all boards, i.e. that in the conditions of variable air humidity each board behaves differently. However, the conclusions are different if the data on thickness swelling reached during the study period (Table 7) are considered.

All types of boards were significantly different compared to the control board $3 \mathrm{~N}$, while there was no difference among the boards of similar construction. So, there was no significant difference between the boards $3 \mathrm{~T}$ and $5 \mathrm{~T}$ (boards composed of treated veneers only), nor in the comparison of boards composed of different combinations of thermally treated and untreated veneers - TNT, TNTNT and T3NT. It is interesting that there was no significant difference in the comparison of 5T and TNTNT boards, which means that the middle veneer sheet, in spite of the lowest exposure to environmental moisture, contributed to the decrease in thickness swelling of the observed board.

As in practice, the change in thickness is more important than the change in moisture content, it can be concluded that the observed categories of boards present the boards of similar properties.

\section{CONCLUSIONS}

\section{ZAKLJUČAK}

Based on the examination of plywood panels produced by combining the thermally treated and untreated poplar veneers, it was concluded that the thermal modification process had a positive effect on the decrease in moisture absorption of the panels. It was also concluded that, with the increased amount of thermally treated veneers in the plywood panels, the values of the observed properties decreased.

The calculated values of ASE (anti-swelling efficiency) showed that the three-layer board exclusively composed of thermally treated veneers (3T), and the five-layer board (5T) achieved the highest values, which was expected.

The analysis using F-test at the significance level of $95 \%$ confirmed that all boards had significantly different moisture contents. However, the analysis of thickness swelling showed that there were no significant differences among the boards of similar construction.

The results presented in this paper proved that the use of thermally treated veneers in plywood production contributed to the improvement of their properties and their resistance to higher air humidity and moisture.

\section{REFERENCES}

5. LITERATURA

1. Akyildiz, M. H.; Ates, S., 2008: Effect of heat treatment on equilibrium moisture content (EMC) of some wood species in Turkey, Research J. Agric. Biol. Sci. 4 (6): 660-665.

2. Awoyemi, L.; Jones, I. P., 2010: Anatomical explanations for the changes in properties of western red cedar (Thuja plicata) wood during heat treatment, Wood science and technology, 45 (2): 261-267. http://dx.doi.org/10.1007/s00226-010-0315-9.

3. Boonstra, M. J.; Tjeerdsma, B., 2006: Chemical analysis of heat treated softwoods. Holz Roh- Werkst 64: 204-211. http://dx.doi.org/10.1007/s00107-005-0078-4.

4. Candana Z., Buyuksarıa U., Korkut S., Unsala O., Cakicier N., 2012: Wettability and surface roughness of thermally modified plywood panels, Industrial Crops and Products 36: 434-436. http://dx.doi.org/101016/j.indcrop.2011.04.024.

5. Cao, Y.; Lu, J.; Huang, R., 2012: Increased dimensional stability of Chinese fir through steam-heat treatment, Eur. 
J. Wood Prod., 70: 441- 444. http://dx.doi.org/10.1007/s00107-011-0570-y

6. Glavaški, L.; Popadić, R., 1997: The research of the influence of drying on the change in form of poplar lumber, Proceedings of $3^{\text {rd }}$ international conference on the development of forestry and wood science/technology - Volume 1: 481-486.

7. Kamdem, D.; Pizzi, A.; Jermannaud, A., 2002: Durability of heat-treated wood, Holz Roh-Werkst., 60: 1-6. http://dx.doi.org/10.1007/s00107-001-0261-1

8. Kocaefe, D.; Shi, J. L.; Yang, D. Q.; Bouzara, M., 2008: Mechanical properties, dimensional stability, and mold resistance of heat-treated jack pine and aspen, Forest Prod J 58 (6): 88-93.

9. Kubojima, Y.; Okano, T.; Ohta, M., 2000: Bending strength and toughness of heat-treated wood, J Wood Sci 46: 8-15.

10. Lovrić, A.; Zdravković, V., 2009: Influence of the thermal treatments on density, swelling and mass loss of poplar veneer, Prerada drveta 28: 35- 43.

11. Nazerian, M.; Ghalehno, M. D., 2011: Physical and Mechanical Properties of Laminated Veneer Lumber Manufactured by Poplar Veneer. Journal of Agricurtular Science and Technology A 1: 1040-1045.

12. Nazerian, M.; Ghalehno, M. D.; Kashkooli, A. B., 2011: Effect of Wood Species, Amount of Juvenile Wood and Heat Treatment on Mechanical and Physical Properties of Laminated Veneer Lumber. Journal of Applied Sciences 11 (6): 980-987. http://dx.doi.org/10.3923/jas.2011.

13. Poncsak, S.; Kocaefe, D.; Bouazara, M.; Pichette, A., 2006: Effect of high temperature treatment on the mechanical properties of birch (Betula papyrifera), Wood Sci. Technol 40: 647-663. http://dx.doi.org/10.1007/s00226-006-0082-9

14. Rowell R. et al., 2009: Understanding decay resistance, dimensional stability and strength changes in heat treated and acetylated wood, Proceedings of 4th European conference on wood modification, Stockholm: 489-502.

15. Sinković, T.; Govorčin, S.; Sedlar, T., 2011: Comparison of Physical Properties of Untreated and Heat Treated Beech and Hornbeam, Drvna ind. 62 (4): 283-290. http://dx.doi.org/10.5552/drind.2011.1118
16. Shi, J. L.; Kocaefe, D.; Zhang, J., 2007: Mechanical behaviour of Quebec wood species heat-treated using ThermoWood process, Holz Roh- Werkst 65: 255-259. http://dx.doi.org/10.1007/s00107-007-0173-9.

17. Šoškić, B.; Popović, Z., 2002: Svojstva drveta- udžbenik, Beograd, Šumarski fakultet.

18. Tjeerdsma, B. F.; Militz, H., 2005: Chemical changes in hydrothermal treated wood: FTIR analysis of combined hydrothermal and dry heat-treated wood, Holz RohWerkst 63: 102-111. http://dx.doi.org/10.1007/s00107-004-0532-8

19. Tjeerdsma, B. F.; Boonstra, M.; Militz, H., 1998: Thermo modification of non-durable wood species. Part 2. Improved wood properties of thermally, International Research Group Wood Pre., Document no NoIRG/WP 9840124.

20. Unsala, O.; Candana, Z.; Buyuksarıa, U., 2010: Effects of thermal modification on surface characteristics of OSB panels, Wood research 55 (4): 51-58.

21. Yildiz, S., 2002: Physical, mechanical, technological and chemical properties of beech and spruce wood treated by heating, $\mathrm{PhD}$ disertation, Karadeniz Tech. Univ., Trabzon, Turkey.

22. Yongjian, C.; Jianxiong, L.; Rongfeng, H., 2010: Increased dimensional stability of Chinese fir through steam-heat treatment, Eur. J. Wood Prod, Online First ${ }^{\mathrm{TM}}$, 24 August 2011. http://dx.doi.org/10.1007/s00107-011-0570-y

23. Zdravković, V.; Lovrić, A., 2010: Influence of thermal treatments on wettability and water spread on the surface of poplar veneer, Paper presented at First Serbian Forestry Congress, held on 11-13 November, Faculty of Forestry, University of Belgrade.

\section{Corresponding address:}

Associate Professor VLADISLAV ZDRAVKOVIĆ, Ph.D.

Department of Wood Processing

Faculty of Forestry, University of Belgrade

Kneza Višeslava 1

11030 Belgrade, SERBIA

e-mail: vladislav.zdravkovic@sfb.bg.ac.rs 